\title{
Arts, Sciences, Humanities: Triangulating the Two Cultures
}

\section{Catherine Belling}

When I was sixteen, my physics teacher told me that if I took literature and art for my final high school subjects, as I wanted to, rather than mathematics and science, I would "only ever be a housewife." The curriculum was designed to make it an either/or decision. I took science. I wonder how late-twentieth century Anglophone education might have been different if that convenient binary had not so easily been assimilated as self-evident. The distinction between the two cultures was based, proximately at least, not on differences in methods or objects of study but on amateur ethnography, comparing two groups: the scientists Snow worked with during the day with the literary colleagues he socialized with at night (Snow 2). This misalignment generated for Snow the observation that scientists (at work) and literary types (at play) were mutually unintelligible, and that the fault lay with what he considered a traditional conservative literati who were unwilling to adapt to the specialized scientific discourses he saw as the language of the future. A misconstrual of relative accessibility and difficulty resulted.

In medical education, for example, a version of Snow's binary is sometimes defensively invoked to support the humanities in medicine: as well as its taken-forgranted science, there is what is called an art of medicine. Four years after C.P. Snow's Rede lecture, John Talbott, editor of the Journal of the American Medical Association, objected to the application of a similar dichotomy to clinical practice: 'Common speech tries to distinguish between the 'artist' and the 'scientist.' There is a confused notion that one uses emotion and intuition,... . achieving great effects without knowing how or why, but that the other, employing rational analysis, is cold and precise, analytical and detached, surrounded by highly complex instruments that baffle the lay mind" (142). Forty years later, JAMA's ethics journal reveals the distinction's longevity in a case about a medical student's concern that his lack of diagnostic and procedural experience keeps him from offering patients anything more than his "bedside manner" (Kirkpatrick 452). The case's title reduces this complex state to a simplistic dichotomy - "Putting it all together: The Art and Science of Medicine." This is reinforced in the commentary: "technical healing and the art of healing are two sides of the medical care coin" (Kirkpatrick 453). The technical doing - is confused with the scientific - knowing - and both, being hard, are contrasted with art as an undefined practice inscrutably situated in the demeanour of the physician. The question "Is good bedside manner important if physicians can cure patients with their technical experience?" produces an implied "no": "there comes a time when science cannot stave off death or suffering, ... . but the practitioner of the art of healing always has something to offer ..." (Kirkpatrick 453).

To imagine medicine as cleanly divisible into two disciplines (or cultures), even if one imagines them as two sides of the same coin (a common move), is to exclude the very kind of thinking that might recognize and resolve some of the challenges facing health care. The art/science binary leaves no room for approaches to health care based, for example, in rigorous, historically-informed attention to the precise use of language, or in the recognition that the clinical care of a patient is at a second order of application, since pure science is applied - or translated - into technologies of diagnosis and therapeutics, and these are then in turn applied to each 
specific instance of patient care. Both levels of application are mediated neither by science nor by art but by an entirely discursively-constructed set of communicative and interpretive practices: the material of the humanities disciplines. But as long as medicine understands itself as two-sided, as a science and an art (or as technical ability and bedside manner), its practitioners will be kept from understanding fully what they do and how it works. The dualism popularized and naturalized after Snow forecloses the possibility of questioning the epistemology, ethics, and language of both biomedical science and clinical practice.

This uneasy pairing of science and art excludes the humanities. Blinkered by Snow's binary, it is all too easy to lump the humanities with art. Many who strongly support practices broadly termed the medical humanities make this mistake as a matter of course. Doing so deprives medical researchers, practitioners, and educators of a position from which they might understand their work as an historically, socially, and culturally contingent activity. Such a position would not diminish any of the massively significant value either of medical research or of compassionate care, but it would remediate an aporia that arguably sustains many of the problems currently facing western medicine. It need not have been this way: before Snow, there was Huxley. As I will show, Huxley understood the natural sciences, the human sciences, and the creative arts as three interconnected domains. This provides a valuable prehistory for positions adopted by the ScienceHumanities, with its call for a more nuanced understanding of how disciplines interact and collaborate, and of the methods and the politics adopted in doing so.

\section{Huxley's Triad}

In "Science and Art," a speech given in 1883 at the Royal Academy of Art, T. H. Huxley addressed the anxiety in Matthew Arnold's view of science as a threat to liberal education: "I think there are many persons who look upon this new birth of our times," - science - "as a sort of monster rising out of the sea of modern thought with the purpose of devouring the Andromeda of art" (Huxley 682). This mythological caricature establishes an antagonism between unequals, one ugly and predatory, the other beautiful and passive (and bound naked to a rock as a sacrificial offering). But we know the story, and the monster does not get to kill Andromeda. Huxley triangulates the dichotomy, reminding us of the third figure: "Perseus, equipped with the shoes of swiftness of the ready writer, with the cape of invisibility of the editorial article, and it may be said with the Medusa-head of vituperation, shows himself ready to try conclusions with the scientific dragon" (682). Our hero writes, publishes, and, when necessary, scolds violently. He can turn you to stone with his rhetoric. Huxley's Perseus, as public intellectual, critic, or humanities scholar, is heroic not because there is any chance he might kill science (even though he can offer wise critical opposition) in order to rescue art (who is less passive than she looks and does not really need rescuing at all), but because he gives us a vantage point from which to reconsider the terms of Arnold's purported fear of science as the enemy of art.

Huxley warns us against assuming we know how the story ends: Perseus should not just attack the monster (it may win); science instead "respects the lady (art) and desires nothing more than to see her happily settled and annually producing a flock of charming children" (works of art, that is) (682). Obviously a great deal more can be said about Huxley's analogy (and its intended reception), but one point is crucial here: Perseus, the intervening third element - the humanities - acts as an interpreter and mediator. We might imagine Medusa's head as a sort of pause button, 
freezing things in place so Perseus can say stop, wait, what's the story here? - and then negotiate a fruitful truce based on a more precise definition of terms.

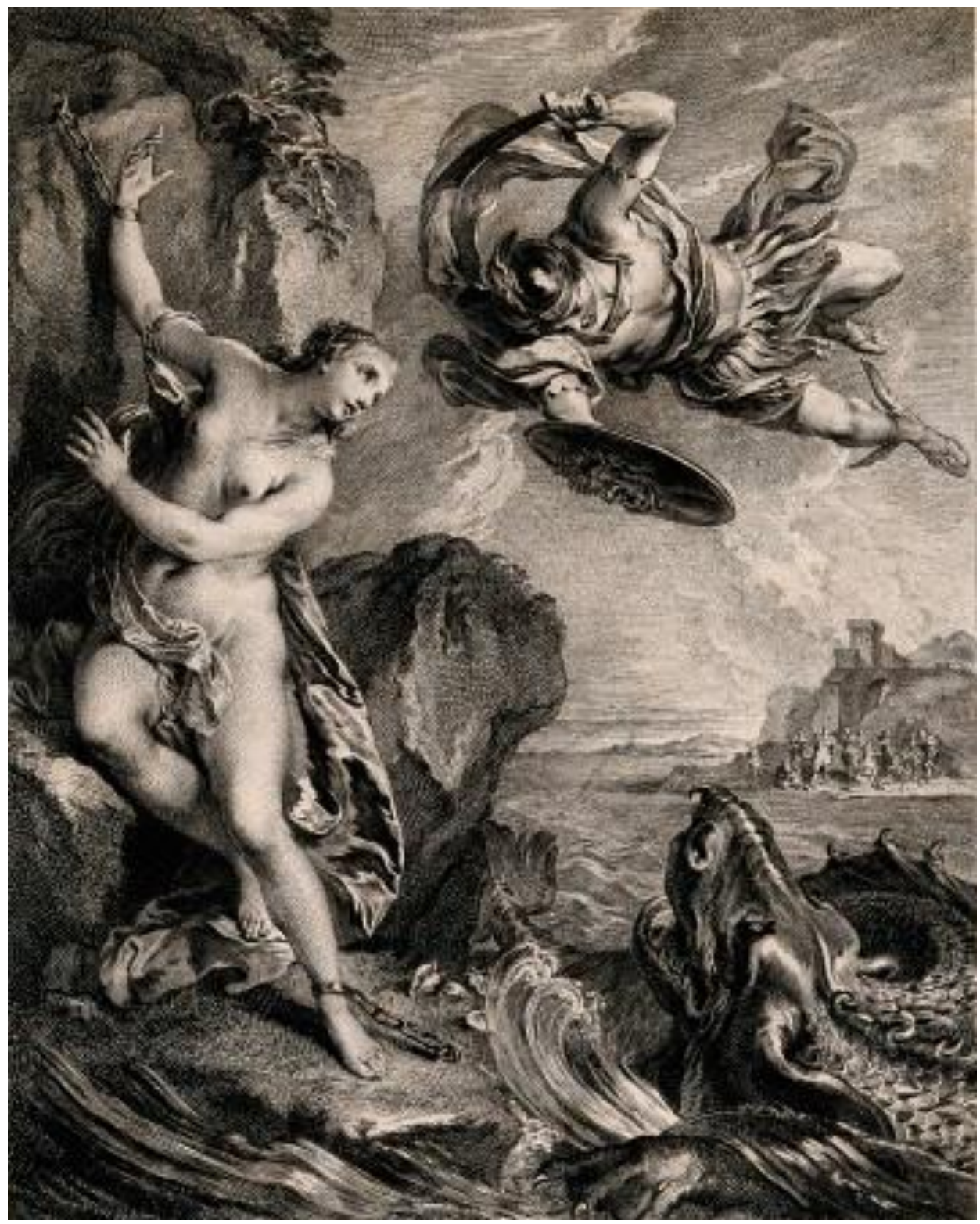

Fig. 1.

Tiziano Vecelli, "Perseus and Andromeda. Engraving by Audran after Titian." Wellcome Collection

\section{Shakespeare, Mammography, and the Second Law of Thermodynamics}

Re-inserting Perseus into the picture of Andromeda and the sea monster enables us to see the misalignment that, I think, has made the naturalizing use of Snow's binary so harmful. This can be demonstrated by considering a letter to the editor published in The Times of London in August 2017. In the face of concern over a too-extreme pendulum swing toward STEM in British secondary education, molecular biologist P. J. G. Butler was responding to an opinion piece in which journalist Libby Purves warned against a rivalry between science and arts. Butler claims that scientists are better educated than those "in the arts and humanities"; as evidence, he describes how he has "enjoy[ed] discussions with colleagues ... about music, theatre and art, and [. . . had] regular chats about that week's programme at the Arts Theatre." This, he 
says, demonstrates scientists' interest in and knowledge of "the arts and humanities," as opposed to those on the other side of the binary, who do not seem to aspire to an equivalent "interest and knowledge in the sciences." Butler's point is a variation on Snow's own much-repeated claim that most of his friends in the arts were stumped when he asked them to "describe the Second Law of Thermodynamics," even though, as he saw it, this was "asking something which is about the scientific equivalent of: 'Have you read a work of Shakespeare's?'” (Snow, 15). Like Snow's, Butler's analogy is misaligned, not only by clumping "arts and humanities" together, but also because, lacking the perspective of the humanities, he sees neither science nor art clearly.

To realign the analogy, we (taking the role of Perseus) must see that consuming (enjoying, appreciating, criticizing) a work of creative art does not require an understanding of how it works. Let's say the molecular biologist and his friend, a biochemist, have both seen a recent production of Macbeth - although it could as well be a television sitcom or a comic book, for the difficulty or cultural prestige of the object does not matter. The scientists chat about the play - no, they exchange thoughtful and well-supported opinions, applauding the special effects in the witches' scenes, disagreeing about the effectiveness of an unconventional delivery of the "brief candle" speech, wondering whether the parallels they saw with current news on Scottish nationalism were intended by the producers, and so on.

Meantime, a painter and her friend, a poet, find that each has recently undergone a routine screening mammogram. They make observations about the experience, comparing advice given by their GPs (perhaps one doctor recommends self-exams, the other does not), media coverage of changes to these recommendations, and of the probability of false positives and unnecessary biopsies. One found the procedure more painful than the other did. Perhaps they speculate about a friend who recently tested positive for the BRCA1 genetic predisposition to breast cancer. This is the equivalent of Butler's engagement with art. No specialist expertise is needed in either conversation but, forced by Snow's binary into clumping together the arts and the humanities, Butler appears to disregard the fact that there is more to understanding Macbeth than viewing or reading it. Our poet, on the other hand, is under no illusion that she understands the physics of ionizing radiation or the pathology visualization needed to generate the conclusion that her breast tissue looks normal.

Given time we might reverse engineer Snow's two cultures from this more accurately aligned starting point - see figure 2 - and perhaps trace out the different accounts of expertise, from the ubiquitous to the specialized, that each stage entails (see Collins and Evans). Discussing an experience, evaluating its quality and exploring its meaning, is the social processing of a cultural object. Specialized knowledge and vocabulary are not necessary, despite differences in access to more or less sophisticated ways of processing and articulating the experience. Some people will not be able to afford either experience; some will choose not to undergo them. All these products depend on the technical application of knowledge of the natural world, the knowledge we usually think of as scientific yet, like having a mammogram, experiencing a work of art does not require an understanding of the technological applications of science that make it available: theatre lighting, say, or video streaming, or the printing press. Or, more to the point here, that fundamental human technology: language. To appreciate Macbeth you do not need to understand or even notice prosody, dramatic form, the evolution of English orthography, the political context of the play's first performances, the history of its production in the twentieth or eighteenth century, and so on. You do not need to have a theory of tragedy, or of the 
way soliloquy generates a newly-emerging model of the self, or even the vocabulary needed to parse all the metaphors or other figures of speech. In this model, an artistic product and a biotech product are both generated by a complex of socio-cultural activities that include scientists and artists as well as practitioners at multiple levels of specialization. But most important here is the triangulation: the products of science and of the creative arts, and of the technologies that emerge from and facilitate the practices of both, all require the disciplines of the humanities in order to make sense, to be ethically enacted, to be rewarded or discouraged - to be understood as massively complex products of human knowledge of, response to, and action in the natural world.

If Perseus is our humanities hero - philosopher, historian, ethnographer, economist, or linguist - then the objects of his attention are both, and equally, Science and Art. The humanities are not defined by their impossibly huge set of objects human activity and its products - but by their methods: the description, interpretation, and evaluation of what people make, in and of the (formerly) natural world. If Huxley's triad had not been overtaken by the frustrating need for neat oppositions, the terms of conversations like this - conversations invited by ScienceHumanities would have had very different dynamics. 


\section{Works Cited}

Butler, P.J.G. "Letter to the editor: Historic rivalry between science and the arts." Times of London, 22 Aug. 2017. www.thetimes.co.uk/article/historic-rivalrybetween-science-and-the-arts-262250ndp. Accessed 11 Dec. 2017.

Collins, Harry, and Robert Evans. Rethinking Expertise. U of Chicago P, 2007.

Huxley, T.H. (1883), "Science and Art." The World's Great Speeches, 4th ed. Dover Publications, 1999, pp. 682-683.

Kirkpatrick, J.N. Commentary on "Putting it All Together: The Art and Science of Medicine." Virtual Mentor: American Medical Association Journal of Ethics, vol. 8, no.7, 2006, pp. 452-458.

Purves, Libby. "Science and Arts Shouldn't be Seen as Rivals." Times of London, 21 Aug. 2017. www.thetimes.co.uk/article/science-and-arts-shouldnt-be-seen-asrivals-cddlhfxzv. Accessed 11 Dec. 2017.

Snow, C.P. The Two Cultures. Introduction by Stefan Collini, Cambridge UP, 1998.

Talbott, John. 'Editorial: The 'Art' and 'Science' of Medicine." JAMA, vol. 184, no. 2, 13 Apr. 1963, pp. 142-143.

Vecelli, Tiziano. Perseus and Andromeda. Engraving by Audran after Titian. 1554-56, Wellcome Collection, London. 
Fig. 2.

\begin{tabular}{|c|c|c|}
\hline & 1. "SCIENCE" & 2. "ART" \\
\hline consumer & e.g. a poet & e.g. a molecular biologist \\
\hline product & $\begin{array}{c}\text { e.g. MAMMOGRAM } \\
\text { (biotechnology) }\end{array}$ & $\begin{array}{c}\text { e.g. MACBETH } \\
\text { (art) }\end{array}$ \\
\hline Informed by (cultural) context of & $\begin{array}{c}\text { public health, early disease } \\
\text { detection, screening programs }\end{array}$ & $\begin{array}{c}\text { theater-going, story consumption, } \\
\text { bardolatry }\end{array}$ \\
\hline provided and performed by & $\begin{array}{c}\text { radiography tech, radiologist, } \\
\text { pathologist, etc }\end{array}$ & $\begin{array}{c}\text { actors, set designers, lighting and } \\
\text { sound engineers, etc }\end{array}$ \\
\hline In specialized setting & radiology suite & Theater \\
\hline Prescribed or motivated by & Primary care physician / GP? & Critic? \\
\hline
\end{tabular}

\section{THE CONSUMER / PATIENT / AUDIENCE DOES NOT NEED DIRECT ACCESS TO ANYTHING BELOW THIS} LINE

\begin{tabular}{|c|c|c|}
\hline $\begin{array}{c}\text { Made possible by an inventor or } \\
\text { creator }\end{array}$ & Inventor(s) of mammography & Shakespeare \\
\hline $\begin{array}{c}\text { who developed the product by } \\
\text { translating and applying ... }\end{array}$ & $\begin{array}{c}\text { Medical imaging technology } \\
\text { informed by knowledge of cancer } \\
\text { pathophysiology }\end{array}$ & $\begin{array}{c}\text { Available verbal vocabulary, } \\
\text { dramatic forms, philosophical, } \\
\text { psychological, religious ideas, } \\
\text { existing histories of Scotland }\end{array}$ \\
\hline $\begin{array}{c}\text { (pure science, or result of research, } \\
\text { study, observation, experience, } \\
\text { outside of scientific method)... }\end{array}$ & $\begin{array}{c}\text { physics } \\
\text { oncogenesis } \\
\text { genetics } \\
\text { narrative and performative } \\
\text { conventions }\end{array}$ \\
\hline $\begin{array}{c}\text { expoduced by specialized } \\
\text { expertise in the study of }\end{array}$ & $\begin{array}{c}\text { the physical-biological world: } \\
\text { nature }\end{array}$ & $\begin{array}{c}\text { human activity and its products } \\
\text { cultural world: }\end{array}$ \\
\hline
\end{tabular}

So what about the humanities?

\begin{tabular}{|c|c|c|}
\hline $\begin{array}{c}\text { The human activities above are } \\
\text { ALL equally amenable to being the } \\
\text { object of study examined, } \\
\text { explained, evaluated by: }\end{array}$ & \begin{tabular}{|}
$|c|$ \\
HUMANITIES / SOCIAL SCIENCES \\
History, philosophy, linguistics, epistemology, literary theory, ethics, \\
aesthetics, economics, jurisprudence, science and technology studies, \\
rhetoric, anthropology, sociology, philology...
\end{tabular} \\
\hline ...by asking, for example: & $\begin{array}{c}|c| \\
\text { How has breast cancer diagnosis } \\
\text { changed over time? }\end{array}$ & $\begin{array}{c}\text { Who was present at the first } \\
\text { production of Macbeth? }\end{array}$ \\
& $\begin{array}{c}\text { Who is paying for this } \\
\text { mammogram? Is this payment } \\
\text { structure just? }\end{array}$ & $\begin{array}{c}\text { What social effect does the local } \\
\text { arts council achieve by funding } \\
\text { Shakespeare rather than a less elitist } \\
\text { art form? }\end{array}$ \\
& $\begin{array}{c}\text { Should a clinician use fear tactics to } \\
\text { persuade a patient to get a } \\
\text { mammogram? }\end{array}$ & $\begin{array}{c}\text { What contemporary medical beliefs } \\
\text { informed Lady Macbeth's hand- } \\
\text { washing scene? }\end{array}$ \\
& $\begin{array}{c}\text { Why should we anticipate disease in } \\
\text { the absence of symptoms? }\end{array}$ & $\begin{array}{c}\text { What does it mean to act violently } \\
\text { in order to bring about a } \\
\text { supernaturally predicted outcome? }\end{array}$ \\
\hline
\end{tabular}

